\title{
"Reading to Learn, Learning to Write" Pedagogy: How Effective is it on Teaching Narrative Writing to Non-Chinese Speaking Students?
}

\author{
Mark Shiu-kee Shum*, Dan Shi \\ Faculty of Education, the University of Hong Kong, China \\ *Corresponding Author: kiwihappy761@hotmail.com, stellashi@hku.hk, mskshum@hku.hk
}

Copyright $\bigcirc 2017$ by authors, all rights reserved. Authors agree that this article remains permanently open access under the terms of the Creative Commons Attribution License 4.0 International License

\begin{abstract}
The current paper aims to introduce the 'Reading to Learn, Learning to Write” (R2L) pedagogy [11] and its application in teaching Chinese narrative writing to non-Chinese speaking (NCS) students in Hong Kong. Based on the needs of the NCS students in Chinese language learning for education and employment in Hong Kong, R2L pedagogy functions as an effective toolkit for L1 Chinese teachers to teach L2 NCS students to read and write Chinese texts successfully. Guided by the teaching and learning cycles accentuated in R2L pedagogy, sufficient scaffolding will be provided for students with teachers' explicit inculcation. With a view to understanding the effect of using R2L pedagogy on genre writing, students' pre- and post-tests representing their different levels of achievement (low, intermediate, high) will be evaluated and compared by R2L assessment criteria incorporating the four language dimensions of context, discourse, grammar, and graphic features [11]. The findings show a significant improvement of NCS students' narrative writing in the post-tests after the pedagogic intervention in comparison with their pre-tests. It is hoped that the R2L-based pedagogic practices can be served as a teaching reference for L1 language teachers on their way to L2 language education.
\end{abstract}

Keywords Reading to Learn, Narrative Writing, Writing Assessment

\section{Introduction}

Hong Kong is a multi-ethnical society where western and eastern culture meets. Due to its colonial history, a large proportion of local residents currently in Hong Kong are non-Chinese language speakers. They are mainly from South Asian ethnic minorities of Pakistanis, Nepalese, Indians, etc. They immigrated to and settled down in Hong Kong because of the historical reason since then, and learnt to adapt to this new environment together with their own generations. Its population has been on an increase trend from making up 5\% of the whole population in Hong Kong in 2006 to 6\% in 2011 according to the government census, as their next generation has proliferated in the recent years [1, 2]. However, the main medium of communication used in Hong Kong is Cantonese. Their linguistic barriers hinder their involvements in the main social activities and hamper their development in the local mainstream society, which further leads to their positioning in the underprivileged sections of the community [15]. In order to change their disadvantaged socio-economic status in Hong Kong, acquisition of Chinese language proficiency is the key to success.

"Reading to learn, learning to write" R2L pedagogy, originating from Australian Systemic Functional Linguistic school [4, 5], was first put forward by Rose and Martin [11], which is intended to assist Australian aboriginal students in learning English as second language [8, 9, 12]. It is a genre-based teaching method, accentuating explicit instruction of reading from the whole text level to sentence and word level in order to inform students' genre writings and improve their literacy capacity $[6,7,10,13,16]$. It is highly emphasized that the meaning of language and its semantic function cannot be fully grasped by the students until helping them get into the whole text level and this is where genre starts to work, which contradicts with the traditional way of implicit teaching excessively focusing on lexical, phrasal and syntactically levels and meanwhile overlooking the importance of information delivered in the whole-text level. It also requires teachers to learn knowledge not only about pedagogy, but also about language, in order to enhance students' language proficiency and more importantly enable their learning through language to achieve all-subject academic performance and overall development.

\section{2. "Reading to Learn, Learning to Write" R2L Pedagogy}

R2L pedagogy consists of three levels of pedagogic support in facilitating students' learning of reading and 
writing [11]. The integration of reading and writing has been an emphasis in combining teaching and learning cycles into a coherent whole [11]. The first level contains preparing before reading, joint construction and independent writing [11]. Preparing before reading aims to enable students to be immersed with the background information and the gist of the target text with teachers' guidance, which helps students to challenge a more difficult text beyond their own capability for independent reading. While preparing for reading is designed to facilitate students' reading, joint construction offers strategic assistance for students' writing. Before joint construction, students tend to be equipped with the schematic structure and the language features of the sample text that is typical in its instantiation of the text type. This is where detailed reading is undertaken and contributes. Having been trained with the language and structure of genre writing, the students are directed to compose another text with the same genre together with the teacher on the show board prior to their own independent writing.

The second level involves detailed reading, joint rewriting, and individual rewriting [11]. In detailed reading, students are expected to have a comprehensive and deep understanding of the sample text that has been selected and analyzed based on the teachers' metalinguistic awareness. Along with the teacher-guided word-by-word reading and instruction of the text, students are required to highlight the important words and set phrases that teachers emphasized as a way of incorporating vital information that constructs the thematic meaning of the text. Joint rewriting can be carried out accordingly after taking the notes of the highlighted words on the show board, which focuses on practicing diversified lexicogrammatic features and stage-based plot development of the sample text in different genre types. Having jointly written the first two paragraphs of the sample text with the teachers, students are encouraged to practise the remaining ones on their own in individual rewriting. Hence, detailed reading and rewriting attach great importance to the teaching and learning of genre knowledge, schematic structure, and linguistic features in order to equip students with the capability of model application into their own writing in the individual construction.

The third level accentuates the training of the fundamental language skills of sentence making, spelling and sentence writing [11]. Sentence making is distinct from sentence writing in the sense that the former stresses the sequential arrangements of the words in sentences, whereas the latter emphasizes the writing of new sentences based on the correct spelling of the words. The three different levels of teaching cycles entail different foci of learning, which can be adjusted according to the students' different levels of abilities and achievement. The integration of reading and writing provides a pathway that reading informs writing and writing reinforces reading, as they are mutually constrained, affected and related to benefit students' learning to read and write.

\section{Teaching and Learning Cycle Arrangements}

The current study takes the teaching of narrative writing as an example to illustrate how R2L pedagogy can be applied in classroom practices and how it helps to enhance students' writing abilities. With a view to designing the teaching and learning cycles that specifically cater for the needs of our students, a pre-test is, first of all, undertaken to assist the teacher in identifying the difficulties that students encounter in their writing. Based on the writing problems diagnosed from the pre-test, the teacher then designed the teaching and learning cycles (shown in Figure 1) accordingly underpinned by the R2L pedagogy that are specific to the predicaments that students faced in their pre-test. After the pedagogic intervention, a post-test will be carried out to test the effectiveness of the R2L pedagogy in improving students' genre writing.

Both the pre- and post-tests are evaluated by the R2L assessment criteria, which is composed of four linguistic dimensions of context, discourse, grammar, and graphic features [11]. The dimension of context contains six elements of purpose (the development of genre appropriate to the writing purpose), staging (stages of the text type), phases (steps within each stage), field (thematic gist of the text), tenor (the relationship fostered between authors and readers) and mode (spoken or written). The second dimension of discourse involves lexis (word choices for constructing text field), appraisal (word choices for evaluation), conjunction (logical relations between/within sentences), and reference (the consistency of the pronouns with the things and the people referred). The assessment of grammar, as the third linguistic dimension, emphasizes the appropriateness and diversity of the syntactic structure used in students' writings. The last evaluating dimension is closely associated with the presentation of the text as graphic features, including spelling, punctuation and the use of paragraphs. Each element is ranged from 0 to 3, with a total of 42 as the highest score. 


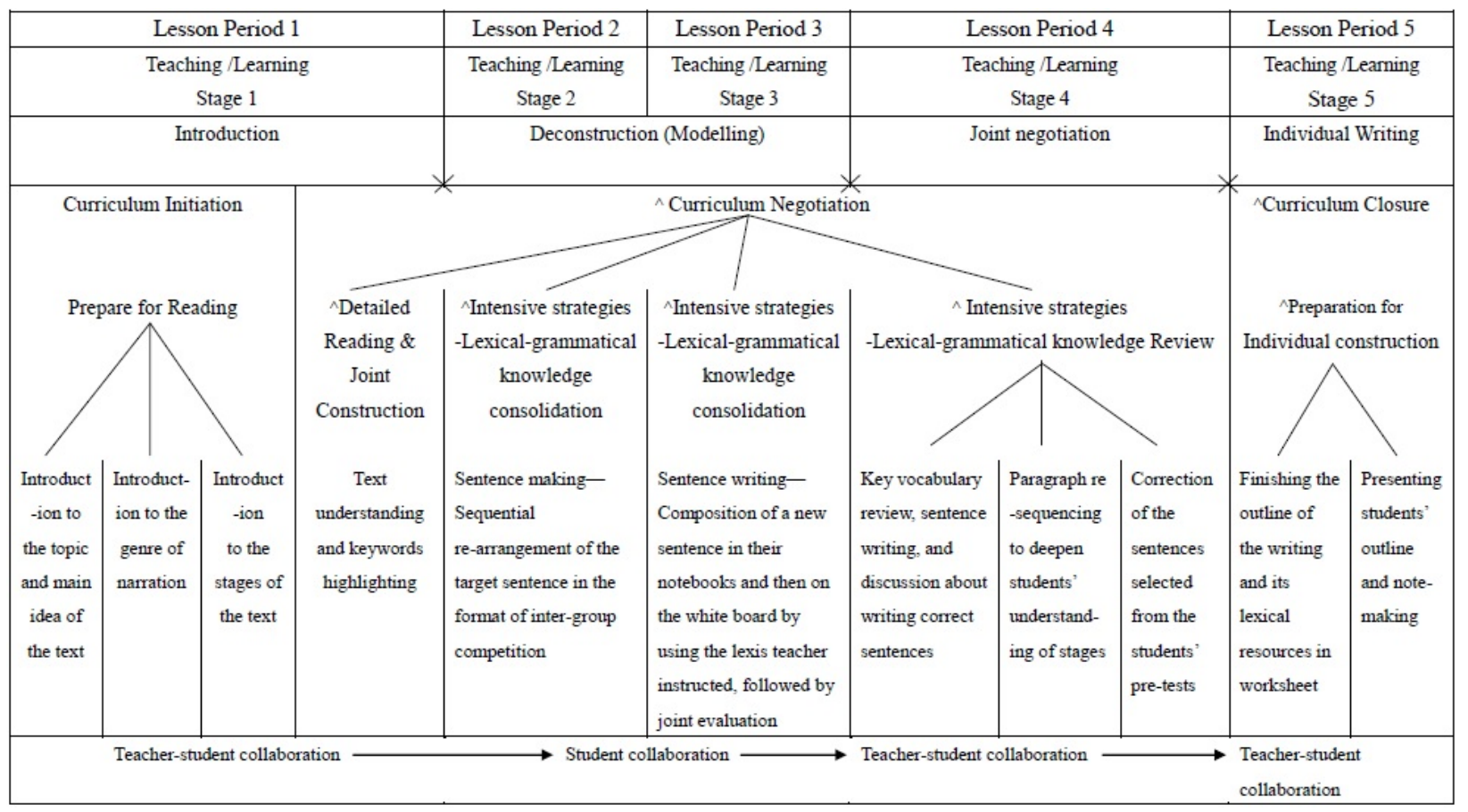

Figure 1. Curriculum macrogenre of teaching narration genre $[3,16]$

In the current study, the pre-test was undertaken with the topic of "a memorable experience" and a comparable title of "a___experience" for the post-test was designed to examine the effectiveness of R2L pedagogy in teaching narrative genre writing. The pedagogic interventions before post-test were conducted in five lessons. The purpose of Lesson 1 is to help students tease out the function, schematic structure of the narrative writing, and the main idea of the sample text in prepare before reading, which sets a foundation for preparing students for the detailed reading of the second paragraph. During detailed reading, students were guided by the teacher highlighting the key words of the sample text, among which questions with different levels of difficulty were posed according to the students' different abilities. Having grasped the schematic structure, language features, and field knowledge of the sample text, students were then led by the teacher to jointly create a new story with the stages of orientation, complication and evaluation in the joint construction. The process of narrative writing together with the teacher provides more scaffolding for the students before their own individual writing.

In Lesson 2, the main focus was on the intensive strategy of sentence making with a view to enabling students to consolidate the syntactical structure and lexical resources of the sample text learnt in Lesson 1. In R2L, sentence making is distinct from sentence writing. As introduced in Section 2, sentence making indicates the sequential re-arrangement of the target sentence, whereas sentence writing signifies the composition of a new sentence based on the intended meaning potential. The pedagogic activity for sentence making was organized in the format of inter-group competition, where the students were competed by finding out the key information based on the teacher's questions and then tearing the part of the paper involving the retrieved key information. Students were then required to re-sequence the different parts of the paper torn previously into a complete sentence for sentence recovery. Attention has been diverted to sentence writing in Lesson 3 to strengthen students' application of the lexical resources used in the sample text. The teacher first selected the lexis of the text, which would then be instructed in detail. Having had a good command of the lexical resources of the text from the teacher's instruction, students were required to create a new sentence in their notebooks by using the lexis introduced. At the meanwhile, they were supported with the teacher's individual assistance. Once finished, students were asked to write their newly created sentences on the whiteboard, which would then be evaluated and corrected by the joint cooperation between the teacher and the students.

At the beginning of Lesson 4, the teacher helped students review the vocabulary that was used for sentence writing in Lesson 3. Based on the sentences they have created, students were further inculcated on how to improve their sentence writing in order to reinforce their ability of not only sentence writing but also writing correct sentences. The second part of Lesson 4 aims to deepen students' understanding of stages in narrative genre writing by re-structuring the sample text written by the teacher based on its corresponding schematic structure and by presenting the rationale behind their restructuring. After being equipped with lexicogrammatical input, students were further trained to correct the problematic sentences randomly selected from the students' writings in the pre-test, which would be supported by the teacher's explanation of these language mistakes as well as their provision of the way for correction. 
Lesson 5 was offered to prepare students for their individual construction. Prior to writing a new narration on their own, students were guided to think about and present the outline of the writing and the lexical resources that feature in each stage in four different groups jointly constructed among the students. Meanwhile, the teacher showed each group's outline presentation on the white board so that other students can make notes on their notebooks. With explicit classroom practices and sufficient scaffolding from the teacher, the students tend to be more confident in fulfilling an independent writing task on their own in Lesson 6.

Table 1. Assessing the Performance of the Low, Intermediate and High Achievers

\begin{tabular}{|c|c|c|c|c|c|c|c|}
\hline \multirow{2}{*}{ Items } & \multirow{2}{*}{ Details } & \multicolumn{2}{|c|}{ Low } & \multicolumn{2}{|c|}{ Intermediate } & \multicolumn{2}{|c|}{ High } \\
\hline & & Pre & Post & Pre & Post & Pre & Post \\
\hline \multicolumn{8}{|l|}{ CONTEXT } \\
\hline Purpose & $\begin{array}{l}\text { How appropriate and well-developed is the genre for the } \\
\text { writing purpose? }\end{array}$ & 1 & 2 & 1 & 2 & 1 & 2 \\
\hline Staging & $\begin{array}{l}\text { Does it go through appropriate stages, and how well is } \\
\text { each stage developed? }\end{array}$ & 0 & 1 & 1 & 2 & 1 & 3 \\
\hline Phases & $\begin{array}{l}\text { Phases are the steps that a text goes through (within each } \\
\text { stage). How well organized is the sequence of phases in } \\
\text { the text? }\end{array}$ & 0 & 1 & 1 & 1 & 1 & 2 \\
\hline Field & $\begin{array}{l}\text { How well does the writer construct the plot, settings and } \\
\text { characters in stories? }\end{array}$ & 1 & 2 & 1 & 2 & 2 & 2 \\
\hline Tenor & How well does the writer engage the reader in stories? & 1 & 1 & 1 & 2 & 1 & 2 \\
\hline Mode & $\begin{array}{l}\text { How highly written is the language for the school stage? } \\
\text { Is it too spoken? }\end{array}$ & 0 & 1 & 0 & 1 & 1 & 2 \\
\hline & Context Total Marks & $3 / 18$ & 8/18 & $5 / 18$ & $11 / 18$ & $7 / 18$ & $13 / 18$ \\
\hline \multicolumn{8}{|l|}{ DISCOURSE } \\
\hline Lexis & $\begin{array}{l}\text { Lexis is the word choices that writers use to build the } \\
\text { field of a text. How well is lexis used to construct the } \\
\text { field? }\end{array}$ & 1 & 1 & 1 & 2 & 1 & 2 \\
\hline Appraisal & $\begin{array}{l}\text { Appraisal is the word choices that writers use to evaluate. } \\
\text { They include feelings, judgements of people, and } \\
\text { appreciations of things. }\end{array}$ & 1 & 1 & 1 & 2 & 2 & 2 \\
\hline Conjunction & $\begin{array}{l}\text { Conjunction is the logical relations between sentences, } \\
\text { and within sentences. Is there a clear logical relation } \\
\text { between all sentences? }\end{array}$ & 0 & 1 & 0 & 2 & 1 & 2 \\
\hline Reference & $\begin{array}{l}\text { Reference is the words that are used to keep track of } \\
\text { people and things through a text. Is it clear who or what } \\
\text { is referred to in each sentence? }\end{array}$ & 0 & 2 & 1 & 2 & 1 & 2 \\
\hline & Discourse Total Marks & $2 / 12$ & $5 / 12$ & $3 / 12$ & $8 / 12$ & $5 / 12$ & $8 / 12$ \\
\hline \multicolumn{8}{|l|}{ GRAMMAR } \\
\hline Grammar & $\begin{array}{l}\text { Accuracy and variety of grammatical conventions of } \\
\text { written Chinese }\end{array}$ & 0 & 1 & 1 & 1 & 1 & 2 \\
\hline & Grammar Total Marks & $0 / 3$ & $1 / 3$ & $1 / 3$ & $1 / 3$ & $1 / 3$ & $2 / 3$ \\
\hline \multicolumn{8}{|c|}{ GRAPHICAL FEATURES } \\
\hline Spelling & $\begin{array}{l}\text { How accurately spelt are core words (frequent) and } \\
\text { non-core words (less-frequent)? }\end{array}$ & 0 & 1 & 1 & 2 & 1 & 2 \\
\hline Punctuation & How appropriately and accurately is punctuation used? & 1 & 1 & 1 & 2 & 1 & 2 \\
\hline Presentation & $\begin{array}{l}\text { Are paragraphs used? How legible is the writing? Is the } \\
\text { layout clear? }\end{array}$ & 1 & 1 & 1 & 1 & 2 & 2 \\
\hline & Graphic Features Total Marks & $2 / 9$ & $3 / 9$ & $3 / 9$ & $5 / 9$ & $4 / 9$ & $6 / 9$ \\
\hline & Total Marks & $7 / 42$ & $17 / 42$ & $12 / 42$ & $24 / 42$ & $17 / 42$ & $29 / 42$ \\
\hline
\end{tabular}




\section{The Learning Outcomes of the Three Students Representing the Low, Intermediate, and High Levels of Achievement}

The pedagogic intervention was carried out underpinned by the teaching and learning cycles, which were designed based on the R2L pedagogy. Along with the teachers' explicit teaching and sufficient scaffolding, the teaching and learning cycles have been put into practice in the classroom. After the pedagogic practices, the learning outcomes of the three students representing low, intermediate, and high level of achievement have been illustrated via the R2L assessment criteria in the four dimensions of context, discourse, grammar, and graphical features [11].

Table 1 shows the writing performance of the students in low, intermediate and high levels of achievement, respectively, before and after pedagogic intervention. Their writing performances in both pre- and post-test were evaluated by R2L assessment criteria in 4 dimensions with 14 items. In comparison with their pre-tests, students' writing performance in the post-tests has made great progress with respect to the construction of genre-based schematic structure as well as the appropriate and diversified use of increased lexicogrammatical resources. What is worth noticing is that the improvement between the pre- and the post-test among these three representatives is consistently keeping almost the same pace, as the progress rate of all the low, intermediate and high achievers in both pre- and post-tests ranging from around 10 to 12 . The low achiever improved from 7 in the pre-post to 17 in the post-test out of a total score of 42, while the high achiever progressed from 17 in the pre-test to 29 in the post-test, with the intermediate achiever from 12 to 24 . The 14 items of R2L assessment criteria not only inform the teacher of the extent to which the students' writing ability has been enhanced, but also of the aspects in which the students' writing performance has been reinforced. Via the R2L assessment criteria, it can be derived that students at different levels of achievement all made progress in the perspectives of appropriate text structuring, diversified linguistic instantiation, and standard presentation in the process of narrative writing after R2L-based pedagogic intervention. The detailed analysis of each case will be discussed one by one in the following sections. The English version of the texts in the Table 2, 3 and 4 is the translation from each student's Chinese written composition.

The pre-test of the low achiever, as indicated in Table 2, shows that the student has a relatively weak ability in Chinese writing, where half of the writing is composed in non-Chinese alphabetic wordings without semantic meanings. The lack of the Chinese wordings in the text indicates an extremely limited Chinese language proficiency of the student in lexicogrammar for idea expression. The shortage of the lexical reserve and the poor performance in syntactic structuring make the text field imperceptible, leading to little connections between the author and the readers in tenor building. In addition, sentences are loosely arranged one after another without any logics built in conjunctive relations. In the narrative text, the complication and its resolution as integral parts of the plot development have been of great significance in engaging the readers and attracting their attention into the story context. However, the text in the pre-test barely shows any indication of complication, only involving event recording of brotherly playing in the garden and the description of the cats they have accidentally come across. Due to the inappropriate stages used in the pre-test, the phases are found to be out of the picture as well, with the purpose of writing becoming problematic.

Table 2. The Writing Performance of the Low Achiever in the Pre- and Post-tests

\begin{tabular}{|c|c|}
\hline Pre-test Writing & Post-test Writing \\
\hline 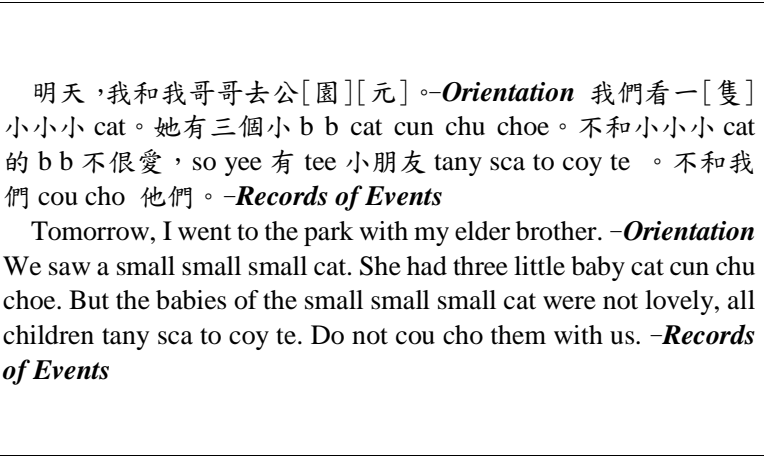 & $\begin{array}{l}\text { 今天, 我和媽外出。我們去公[園] [元]。-Orientation 我看 to 一隻可 } \\
\text { 愛的小 [ 貓] 。他看 to 我和媽媽。我媽媽很怕所以她跑走了。我自巴一 } \\
\text { 個很 [怕], 所以我去找我的媽媽。我不知道我做什麼。很好時我看見 } \\
\text { 我的朋友, 他的姓名是 chanpoheianson } \circ \text { 我有不有見 kwo 我的媽媽。不 } \\
\text { 和他沒見我媽媽。-Complication 我看我媽媽, 我很好快樂。我媽媽很 } \\
\text { 快樂。我們一起去家。我學很 to tong sai。-Evaluation } \\
\text { Today, I went out with mom. We went to the park. -Orientation I saw to a } \\
\text { lovely little [cat]. He saw to me and mother. My mother was very scared so } \\
\text { she ran away. Being along I was very [afraid], so I went to find my mother. I } \\
\text { did not know what I was doing. Very good time I saw my friend, his name is } \\
\text { chanpoheianson. Have I seen my mother. But he did not see my mother. } \\
\text {-Complication I saw my mother, I was very happy. My mother was very } \\
\text { happy. We went home together. I learned very to tong sai. - Evaluation }\end{array}$ \\
\hline
\end{tabular}


According to the problems and difficulties that the student faced diagnosed from the pre-test, R2L-based teaching and learning cycles were applied and facilitated by the teacher's explicit teaching of not only what to write, but also how to write it. Supported by the teacher's sufficient scaffolding, the writing performance of the student representative at the low level of achievement has been greatly reinforced in the post-test. Different from the writing in the pre-test, the written text in the post-test is composed mostly in Chinese only with a little alphabetical spoken Cantonese. The story is first oriented with the events of going out and coming across a lovely cat again. Unlike the recount of events in the pre-test, the complication appears in the post-test with a scaring experience of the author getting lost and being separated with his mother upon cat encountering, which is finally ended by the author's reunion with his mother. The student's trilogy of orientation, complication, and ending in the post-test basically corresponds to the schematic structure of narrative writing, with the complication sparkling to engage the readers into the storyline. However, the ending stage of resolution has not been well elaborated, lacking in a further explanation of how the complication is resolved, with a shortage of phases within the stage accordingly. However, the stage of Evaluation was supplemented as the concluding part of the story. Hence, not only has the student improved in the construction of the schematic structure of narrative writing, but also in the lexicogrammatical choices made for the meaning making process both lexically and syntactically. The reinforcement of the language skills and text structure allocation made the text field straight to the point and intelligible to the readers.

As to the student at the intermediate level, growth in narrative writing has also been detected from Table 3 . In the pre-test, a deficiency of lexical resources in Chinese can conspicuously be found, with a certain amount of the idea expressed in English or in alphabetical Cantonese pronunciation. The lexical and syntactical structure in the student's pre-test also misleadingly follows the language pattern of spoken Cantonese, deviating from the standard mode of written Chinese in genre writing. Besides the shortage of the lexicogrammatical resources for meaning construction, a lack of genre knowledge in the schematic structure of narration is also disclosed by the author's mechanical record of events (first going to the ocean park, eating and playing, finally going home) as in the text type of recount without the involvement of incidental climax of complication that needs to be resolved. The plain recount of what the author was doing chronologically one after another can hardly engage the readers in the story, leading to a weak tenor building in the dimension of context.

Table 3. The Writing Performance of the Intermediate Achiever in the Pre- and Post-tests

\begin{tabular}{|c|c|}
\hline Pre-test Writing & Post-test Writing \\
\hline $\begin{array}{l}\text { 我們一次歏忘的經歷的時上一年我們和友朋 } \\
\text { 一起去海洋公園,-Orientation 我們 tai 很多飯食。 } \\
\text { 我們玩得很開心。我玩了 了尤]樓 kai, flying } \\
\text { swing, hair raiser, 行行。我的友朋很 gang 因為 } \\
\text { hair raiser 很快。我們很 late fan 家。我們很 tired } \\
\text { 和很開心。我希望下次到有得去。-Records of } \\
\text { Events } \\
\text { An unforgettable experience of ours what last } \\
\text { year we went to the Ocean Park with our friends. } \\
\text {-Orientation We tai a lot of rice to eat. We were } \\
\text { very happy. I had a ride on the floor kai, the flying } \\
\text { swing, the hair raiser, walk walk. My friends were } \\
\text { very gang because the hair raiser was very fast. We } \\
\text { fan home very late. We were very tired and very } \\
\text { happy. I hope I could go there next time. - Records } \\
\text { of Events }\end{array}$ & 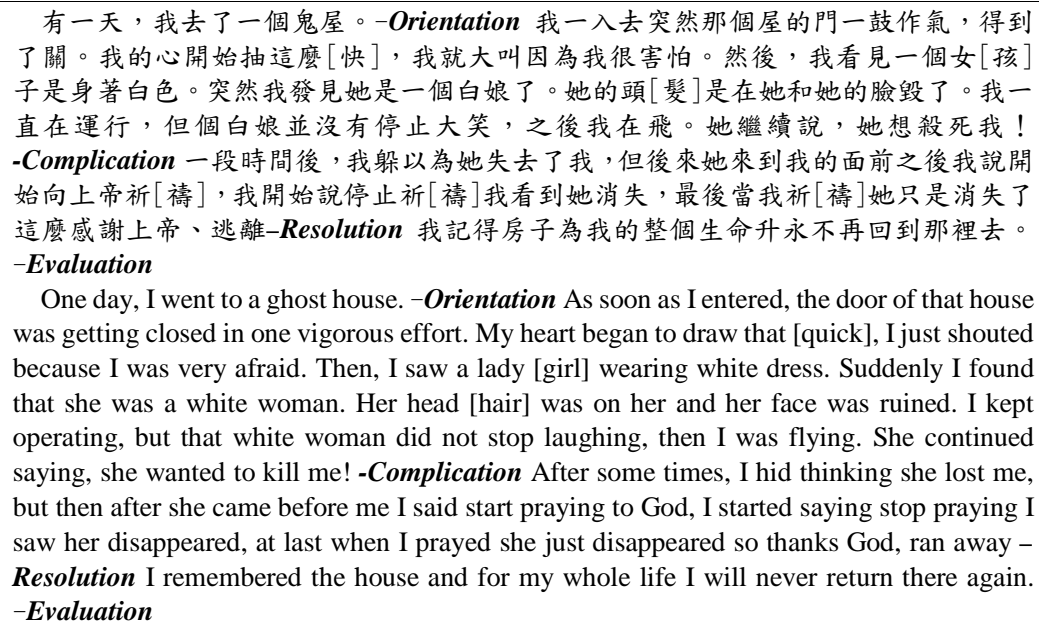 \\
\hline
\end{tabular}


Based on the obstacles identified via the pre-test, the pedagogic intervention was designed typically catering for the need of the student, including his poor genre knowledge of stages and phases of narrative writing, limited lexicogrammatical resources for idea expression, and illogical connection between/within sentences. With the teacher's well-directed instruction and explicit teaching, the effectiveness of the R2L-based pedagogic design has been illustrated in the student's writing performance in the post-test. As shown in the test after pedagogic intervention, the student is able to write a complete Chinese composition without the use of English wordings by following the typical narrative schematic structure of going to a ghost house as an orientation, ghost encountering as a complication, finally ended by his praying for the disappearance of the ghost as a resolution, and evaluated by stating the author's strong unwillingness to the revisit of the haunting house again. The climax constructed by the student creates an intimidating and mysterious atmosphere to stimulate the readers' curiosity of wanting to know more about the plot development, hence engaging them to the story. The resolution of ghost encountering was provided in terms of how and why the ghost disappeared and the author's attitude was evaluated at the end of the story. Therefore, in contrast to the pre-test, the student's capability of appropriate syntactic construction and diversified lexical application has been enhanced greatly in the post-test. Moreover, it was found that the student learnt to use appraisal to express his inner emotion of scaring and panic when he walked into the ghost house and found a female ghost in white dress. The bottom line is that all the frightening incidents have been logically arranged in a chronological order by means of the temporal conjunctions, and occasionally accompanied by the adversative conjunctions to highlight each significant turn of the story line.

Compared with the low and intermediate achievers, as shown in Table 4, the student at the high level of language proficiency performed relatively better in the pre-test in terms of the language used to express his personal experience of home visiting during Mid-autumn Festival. However, deficiency in the genre knowledge of narrative writing and a lack of vocabulary were found to negatively influence the quality of the writing that the student composed in the pre-test. The writing is first oriented with an unforgettable experience during Mid-autumn Festival, followed by a recount of what was done during Mid-autumn Festival. The text is finally ended with the reaction of the people that the author made action to and the reflection of the author himself as an evaluation of the recount. Similar to the performance of the low and intermediate achievers, the student had difficulty in telling the difference between the text types of narration and recount. Recording events in recount is different from resolving a complication in narration. Furthermore, the limited lexicogrammatical resources also constrain the author's ability of expressing both the outer world of happening and his inner sphere of feeling.

Table 4. The Writing Performance of the High Achiever in the Pre- and Post-tests

\begin{tabular}{|c|c|}
\hline Pre-test Writing & Post-test Writing \\
\hline $\begin{array}{l}\text { 每個人有自己的難忘的經歷。 } \\
\text { 我今年中秋節很難忘。 } \\
\text {-Orientation } \\
\text { 我中秋節探訪了(窮)人的家。 } \\
\text { 在那裡, 我送給他們月餅。 } \\
\text {-Records of Events } \\
\text { 他們看見了月餅, 他們十分感 } \\
\text { 動。我也很開心。因為智人是一 } \\
\text { 個好事。 } \\
\text {-Evaluation } \\
\text { Everyone has his unforgettable } \\
\text { experience. My Mid-autumn } \\
\text { Festival this year is very } \\
\text { unforgettable. } \\
\text {-Orientation } \\
\text { I visited (poor) people's home } \\
\text { in the Mid-autumn Festival. } \\
\text { There, I sent mooncakes to them. } \\
\text {-Records of Events } \\
\text { They saw the mooncakes, they } \\
\text { were very touched. I was very } \\
\text { happy as well. Because helping } \\
\text { others is a piece of good thing. } \\
\text {-Evaluation }\end{array}$ & 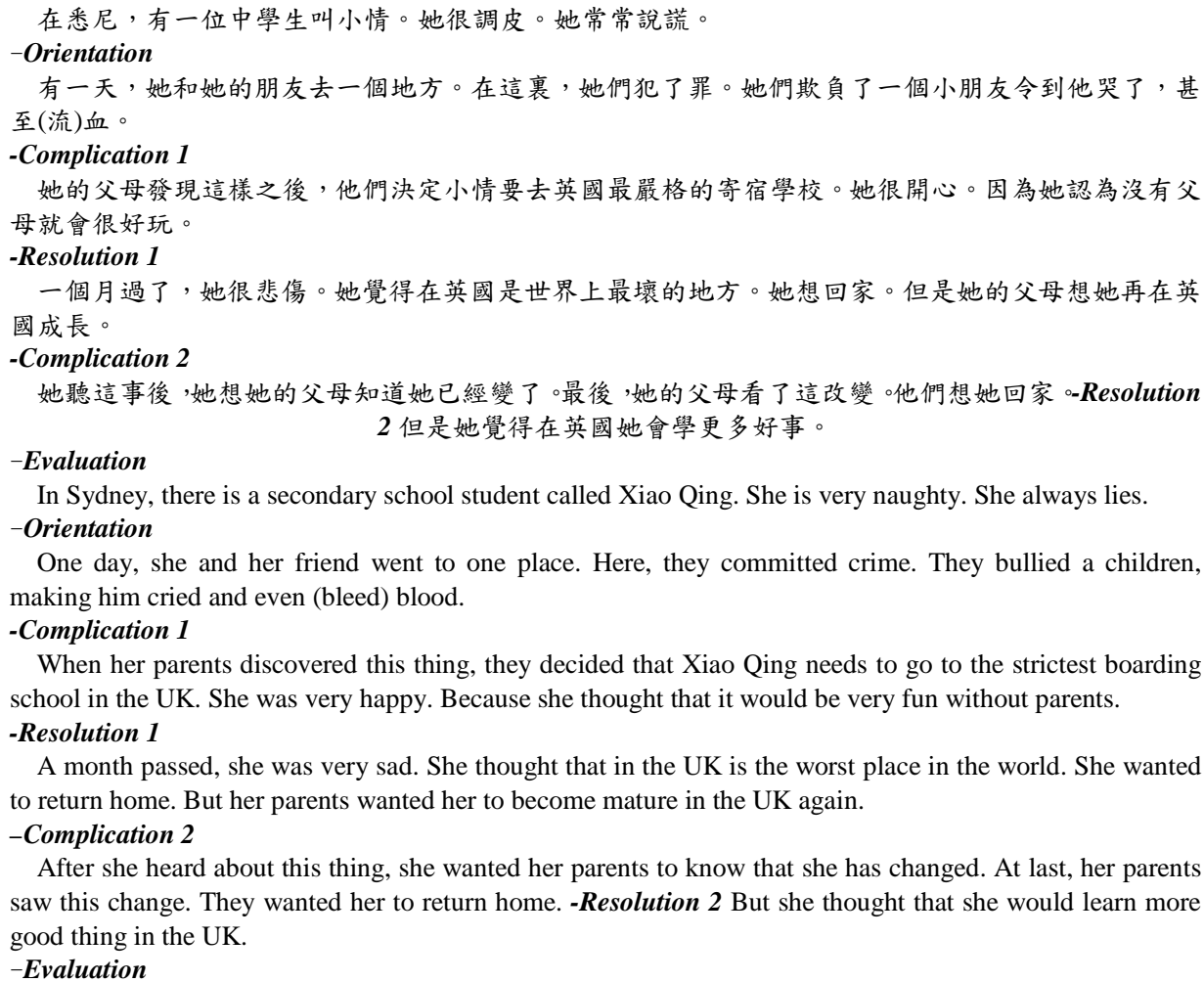 \\
\hline
\end{tabular}


With the teacher's explicit teaching and sufficient support in the process of pedagogic intervention, further improvement was made by the representative of the high achievers. The writing composed in the post-test is more inclined to a narrative story rather than a recount, with the plot, settings and characters constructed to well signify the field of the text. As the plot was designed with a complication of the character Xiaoqing's tragic experience, and concluded with a resolution of her changes after this memorable experience. The readers tend to be attracted by the unpredictable fluctuation of the storyline so as to strengthen the author-reader relationship in establishing the registerian context of tenor. In addition to the improved schematic structure, the student's vocabulary use has been more diversified, featuring not only on the verbal processes to describe the experiential experiences of the main protagonist, but also on the appraisal wordings used to expose the main protagonist's emotional feelings in reaction to this tragic experience, the author's judgement of the character's personality and her moral behaviors, as well as the author's appreciation of the thing connecting the human relations in the story. Besides, the logical liaison throughout the text has been reinforced by the conjunctions indicating temporal, causal and adversative relationship between or within sentences.

\section{Conclusions}

R2L pedagogy is distinct from the traditional teaching method emphasizing students' self-discovery of knowledge in interaction with the teacher's implicit teaching, where students found it difficult to keep pace with each other, leading to widen the gap between the bottom and the top students. In contrast, R2L pedagogy aims to close the learning disparity among students at different levels of achievement via explicit teaching and adequate scaffolding with a view to realizing success for all students. Underpinned by the students' learning obstacles diagnosed from the pre-test, the teaching design of the pedagogic invention made the most of the three levels of R2L pedagogy and was practiced based on the teaching and learning cycles catering specifically for the learning need of the target students.

The tailor-made teaching and learning cycles kept students informed of not only what to write but also how to write it from the teacher's hands-on practical inculcation. Students were trained to be equipped with the genre knowledge of the schematic structure for narrative writing, the lexicogrammatical features specific to the narrative genre, and thematic meaning co-construction of the storyline from the detailed reading and joint construction of the model text. Facilitated by the teachers' step-by-step guidance prior to the students' individual construction, great progress was made clearly illustrated in the writing performance of their post-tests.

The current study with an illustration of the three representatives' improvement in their writing performance from the teaching intervention clearly proves the effectiveness of the R2L pedagogy in facilitating the writing capacity of the students from all different levels of achievement. However, the findings are limited to the typicality of the three student representatives' writing practices, with an extended sample size suggested. Not only their writing performance, but their personal viewpoints towards the use of the R2L pedagogy in their classroom learning process from interview can be another proof for its effective application in Hong Kong context. Having unfolded the positive learning outcomes of the secondary students via the pedagogic interventions, the current study with the use of R2L pedagogy is promising to be applied in teaching Chinese to primary students in Hong Kong. Hopefully, the R2L-based pedagogic practices and the learning outcome of the students derived from the current study could provide teaching references and pedagogic rationale for L1 language teachers and raise their metalinguistic awareness in teaching Chinese to non-Chinese speaking students in Hong Kong and beyond.

\section{REFERENCES}

[1] Census and Statistics Department, (2006). Thematic Report: Ethnic Minorities. Hong Kong: Website of the Census and Statistics Department.

[2] Census and Statistics Department, (2011), 2011 Population Census: Thematic report: Ethnic minorities. Hong Kong: Website of the Census and Statistics Department.

[3] Christie, F. (1997). Curriculum genres as forms of initiation into a culture. In F. Christie and J. R. Martin (eds.), Genre and institutions: Social processes in the workplace and school. London: Cassell.

[4] Halliday, M. A. K. (1985). An Introduction to functional grammar. London: Edward Arnold.

[5] Halliday, M. A. K., \& Matthiessen, C. M. I. M. (2004). An introduction to functional grammar. London: Hodder Arnold.

[6] Hyland, K. (2007). Genre pedagogy: Language, literacy and L2 writing instruction. Journal of Second Language Writing, $16,148-164$.

[7] Hyon, S. (1996). Genre in three traditions: Implications for ESL. TESOL Quarterly, 30(4), 693-722.

[8] Rose, D. (2006). Closing the gap and accelerating learning in the middle years of schooling. Literacy Learning: the Middle Years, 14(2), 32-45.

[9] Rose, D. (2008). Writing as linguistic mastery: The development of genre-based literacy pedagogy. In R. Beard, D. Myhill, J. Riley, \& M. Nystrand (eds.), The SAGE Handbook of Writing Development, 151-166. London: Sage.

[10] Rose, D. (2010). Genre in the Sydney School. In J. P. Gee, \& M. Handford (eds.), The Routledge Handbook of Discourse Analysis. London: Routledge. 
[11] Rose, D. \& Martin, J. R. (2012). Leaning to write, reading to learn: Genre, knowledge and pedagogy in the Sydney school. Sheffield: Equinox.

[12] Rose, D. (2012). Reading to learn: Accelerating learning and closing the gap. Sydney: The Reading to Learn Program.

[13] Rose, D. (2014). Integrating SFL theory with literacy teaching. In F. Yan, \& J. Webster (eds.), Development Systemic Functional Linguistics: Theory and application. London: Equinox.

[14] Shum, M. S. K. (2006). Teaching Chinese report writing: Melbourne and Hong Kong-Implications for Global
Curriculum Sharing. In M. S. K. Shum, et al. (eds.), Teaching writing in Chinese speaking areas. New York: Springer.

[15] Shum, M.S.K., Gao, F., Tsung, L., \& Ki, W.W. (2011). South Asian students' Chinese language learning in Hong Kong: Motivations and strategies. Journal of Multilingual \& Multicultural Development, 32(3), 285-297.

[16] Stockholm Education Administration. (2010). A report on school-based action research: Will the implementation of Reading to Learn in Stockholm schools accelerate literacy learning for disadvantaged students and close the achievement gap? Stockholm: Multilingual Research Institute. 